\title{
STRATEGI PENERBITAN DAN MODEL PENYUNTINGAN DI SOLOPOS SEBAGAI PENOPANG EKSISTENSI PENULIS BERITA
}

\author{
Bela Megawati \\ Pendidikan Bahasa Indonesia FKIP Universitas Sebelas Maret \\ J1. Ir. Sutami No. 16, Surakarta \\ bellamegawati2@student.uns.ac.id
}

\begin{abstract}
The internship activities of editing courses are expected to provide provision and experience to the Indonesian language education students in the field of editing skills. An apprentice editing activity is conducted in Solopos. Solopos is the daily newspaper of Solo Raya area. Therefore, Solopos publishes newspapers on a daily basis. So the editing activities are done every day. This is a challenge for apprentices to edit different manuscripts every day because the news presented in the newspaper every day differs. During the editing process in Solopos using the manual method is to mark words or spelling that are less precise. The editing process also uses the guidelines in the form of KBBI (Smartphone application), inhouse style book from Solopos, and PUEBI in the process of editing.
\end{abstract}

Key Words: editing, method, edit, Solopos

\begin{abstract}
Abstrak
Kegiatan magang praktik mata kuliah penyuntingan ini diharapkan dapat memberikan bekal serta pengalaman kepada mahasiswa Pendidikan Bahasa Indonesia dalam keahlian di bidang penyuntingan. Kegiatan magang penyuntingan dilakukan di Solopos. Solopos merupakan koran harian daerah Solo Raya. Oleh karena itu, Solopos menerbitkan koran setiap hari. Dengan begitu kegiatan penyuntingan pun dilakukan setiap hari. Hal ini menjadi tantangan bagi peserta magang untuk menyunting naskah-naskah berbeda setiap hari karena berita yang disajikan dalam koran setiap hari berbeda-beda. Selama melakukan proses penyuntingan di Solopos menggunakan metode manual yaitu menandai kata atau ejaan yang kurang tepat. Proses penyuntingan juga menggunakan pedoman berupa KBBI (aplikasi smartphone), buku Gaya Selingkung dari Solopos, dan PUEBI dalam proses penyuntingan.
\end{abstract}

Kata Kunci: penyuntingan, metode, menyunting, Solopos

\section{PENDAHULUAN}

Berdasarkan Peraturan Menteri Tenaga Kerja dan Transmigrasi No. Per.22/Men/IX/2009 tentang Penyelenggaraan Pemagangan di Dalam Negeri, pemagangan diartikan sebagai bagian dari sistem pelatihan kerja yang diselenggarakan secara terpadu antara pelatihan di lembaga pelatihan dengan bekerja secara langsung di bawah bimbingan dan pengawasan instruktur atau pekerja yang lebih berpengalaman 
dalam proses produksi barang dan/atau jasa di perusahaan, dalam rangka menguasai keterampilan atau keahlian tertentu. Selaras dengan Peraturan Menteri Tenaga Kerja dan Transmigrasi No. Per.22/Men/IX/2009, kegiatan magang penyuntingan III diharapkan mampu melatih keterampilan dan keahlian mahasiswa penyuntingan. Keterampilan tersebut dapat berupa keterampilan untuk menyunting naskah dan keahlian dalam membangun kemampuan sosialisasi dan berorganisasi dalam sebuah perusahaan.

Pengalaman praktik di tempat magang akan mengasah keterampilan mahasiswa dalam menerapkan ilmu yang didapatkan. Pembelajaran yang bersifat aplikatif didapatkan ketika magang. Adapun penilaian yang akan diberikan mencakup bebrapa aspek sebagai berikut: (1) kedisiplinan, (2) kreativitas, (3) kerja sama tim, (4) produktivitas, (5) kualitas kerja, dan (6) nilai akhir/akumulatif.

Kegiatan magang praktik mata kuliah penyuntingan ini diharapkan dapat memberikan bekal serta pengalaman kepada mahasiswa Pendidikan Bahasa Indonesia dalam keahlian di bidang penyuntingan. Mahasiswa akan belajar secara langsung melalui observasi hingga aplikatif mengenai proses-proses penyuntingan sampai percetakan produk (hasil kerja). Inilah salah satu nilai lebih dari Pendidikan Bahasa Indonesia, selain mencetak calon guru bangsa pun juga mempersiapkan mahasiswanya untuk siap menghadapi tantangan dunia kerja dengan berbekal keterampilan yang didapatkan setelah magang penyuntingan ini.

Kegiatan magang Penyuntingan III memiliki tujuan yang ingin dicapai. Pelaksanaan magang sebagai salah satu bentuk aplikasi terhadap Tri Darma Perguruan Tinggi terutama dalam bidang pengabdian masyarakat dan juga untuk mengetahui gambaran dunia kerja seorang editor. Selain hal itu, tujuan lain diadakannya kegiatan magang ialah mengimplementasikan teori-teori yang telah didapatkan mahasiswa selama masa perkuliahan; memberikan bekal keahlian bidang penyuntingan sebagai alternatif pilihan karier di masa depan; dan melatih mental mahasiswa di lapangan kerja kehidupan yang sesungguhnya.

Dikutip dari Wikipedia, Solopos adalah surat kabar harian pagi yang terbit di Kota Surakarta, Jawa Tengah. Harian ini terbit pertama kali pada September 1997. Penerbitnya adalah PT Aksara Solopos yang juga menguasai saham percetakan PT Solo Grafika Utama, Radio Solopos FM, dan tabloid olahraga Arena. Koran terbesar di eksKaresidenan Surakarta ini didirikan oleh PT Jurnalindo Aksara Grafika (penerbit harian 
Bisnis Indonesia). Kantor Solopos beralamat di Griya Solopos, Jl. Adisucipto, Karangasem, Laweyan, Kota Surakarta, Jawa Tengah, 57145.

Penyuntingan merupakan sebuah proses sunting terhadap naskah yang diperoleh dari penulis atau pengarang dan prosesnya dilakukan oleh editor atau kopieditor di suatu penerbitan ( Rhahmadani \& Astuti, 2013). Kegiatan magang penyuntingan dilakukan di Solopos. Solopos merupakan koran harian daerah Solo Raya. Oleh karena itu, Solopos menerbitkan koran setiap hari. Dengan begitu kegiatan penyuntingan pun dilakukan setiap hari. Hal ini menjadi tantangan bagi peserta magang untuk menyunting naskahnaskah berbeda setiap hari karena berita yang disajikan dalam koran setiap hari berbedabeda.

\section{METODE PENELITIAN}

Metode penelitian yang dilakukan dalam penelitian ini adalah metode kualitatif dengan pendekatan deskriptif analitik. Penelitian kualitatif lebih menekankan pada analisis empirik yang diambil dari berbagai sumber. Pemilihan jenis penelitian ini bertujuan untuk mengungkapkan berbagai informasi kualitatif dengan pendeskripsian yang teliti dan penuh nuansa untuk menggambarkan secara cermat sifat-sifat suatu hal, keadaan, gejala, atau fenomena, tidak terbatas pada sekadar pengumpulan data, melainkan meliputi analisis dan interpretasi mengenai data tersebut (Saddhono, 2012). Menggunakan pendekatan kulitatif karena penelitian ini bertujuan menhasilkan temuan, yang tidak dapat dicapai dengan menggunakan prosedur statistik atau dengan cara kuantifikasi lainnya (Raharjo, dkk., 2017).

\section{HASIL DAN PEMBAHASAN}

Solopos memiliki 22 editor yang terbagi atas editor Solopos cetak, online, dan radio. Editor tersebut terdiri atas editor reguler dan edisi mingguan atau edisi minggu. Tiap editor memiliki 2 reporter yang tersebar di Soloraya yang bertugas untuk memasok dan menulis berita. Reporter-reporter tersebut harus memiliki kemampuan menulis berita yang baik. Terkait hal tersebut, Solopos memfasilitasi dengan mengadakan pelatihan dasar menulis bagi reporter selama tiga minggu. Satu reporter berkewajiban untuk mengumpulkan 5 berita dalam satu hari yang terdiri atas 3 berita besar dan 2 berita kecil. 
Berita besar adalah berita dengan jumlah karakter 1.500-2.500 sedangkan berita kecil adalah berita yang berisi kurang lebih 700 karakter.

Redaksi Solopos mengadakan rapat harian yang dilakukan secara rutin yang mana merupakan salah satu bagian penting dalam proses penerbitan koran. Rapat pertama dilakukan pada pukul 14.00 WIB guna membahas berita apa yang akan menjadi topik utama pada halaman utama koran. Rapat kedua dilakukan pada pukul 19.00 WIB untuk membahas berita-berita terencana yang akan diliput dan ditulis oleh reporter di keesokan harinya.

Kinerja reporter dimulai pada pukul 08.00 WIB dengan melakukan proses pencarian dan penulisan berita. Berita merupakan sajian utama sebagian besar media massa di samping view (opini, pendapat) (Primawan, 2009). Tenggang waktu yang diberikan pada reporter adalah sampai pukul 15.00 WIB untuk menyerahkan naskah berita pada editor. Sedangkan waktu kerja editor adalah pada pukul 14.00 WIB hingga pukul 21.00 WIB. Dalam masa itu, editor harus senantiasa menunggu jika terjadi peristiwa tidak terduga, editor harus dalam posisi siap untuk menyunting naskah sebagai naskah tambahan untuk dicetak. Editor dalam tahap ini melakukan tugas berupa pengeditan naskah dari segi format dan kebahasaan. Hal itu terjadi karena SOLOPOS tidak memiliki editor khusus kebahasaan.

Seorang penyunting tidak hanya menghadapi persoalan-persoalan teknis dalam memperbaiki naskah yang berkaitan dengan kaidah kebahasaan dan gaya selingkung penerbitan (Supriyana, 2018). Ketika dilakukan proses mengedit, editor koran Solopos selain harus mematuhi etika kode etik penyunting, ia juga harus taat akan kode etik jurnalistik. Berdasarkan Peraturan Dewan Pers Nomor 6/Peraturan-DP/V/2008 kode etik jurnalistik diperlukan untuk menjamin kemerdekaan pers dan memenuhi hak publik untuk memperoleh informasi yang benar. Salah satu ciri khas koran Solopos adalah tidak menyebutkan nama pelaku/korban pada tingkat atau level wilayah terendah, misalnya "Pelaku pembunuhan, dengan nama samaran Bunga, tinggal di Desa Gulon".

Sirkulasi atau proses koran terbit di Solopos memiliki beberapa tahap, yaitu tahap pencarian dan penulisan berita oleh reporter, penyuntingan oleh editor, layout, percetakan, dan distribusi. Pertama, tahap pencarian dan penulisan berita oleh rerporter yang tersebar di berbagai kabupaten dan kota di Soloraya. Pencarian dan penulisan berita dilakukan oleh reporter dari pukul 08.00 WIB hingga pukul 14.00 WIB. Kedua, setelah tahap 
pencarian dan penulisan berita oleh reporter kemudian dilanjutkan dengan tahap penyuntingan yang dilakukan oleh editor. Ketiga, berita yang sudah disunting diberikan kepada bagian layout untuk diedit sesuai dengan gaya selingkung cetakan surat kabar Solopos. Keempat, berita yang sudah diedit sesuai dengan gaya selingkung cetakan surat kabar Solopos dicetak terlebih dahulu dengan kertas HVS ukuran A4 untuk mengetahui hasil layout dan pengecekan akhir hasil penulisan berita.

Setelah itu berita yang sudah sesuai dan benar dicetak pada pukul 02.00 WIB dengan menggunakan kertas koran sebanyak 45.000 eksemplar. Kelima, setelah koran dicetak kemudian pada pukul 05.00 WIB diedarkan ke seluruh agen Solopos yang ada di Solo Raya. Pada pukul 08.00 WIB kembali lagi pada tahap pertama yaitu pencarian dan penulisan berita oleh reporter hingga berlanjut ke tahap-tahap berikutnya, begitu seterusnya sirkulasi yang ada di Solopos.

Kegiatan magang penyuntingan 2019 dilaksanakan dari tanggal 7 Januari 2019 dan berakhir pada tanggal 16 Februari 2019. Kegiatan magang penyuntingan di Solopos dilaksanakan selama 6 hari dalam satu minggu dari pukul 17.00-22.00 WIB. Pada hari pertama peserta magang diberi pembekalan singkat mengenai proses editing di Solopos. Peserta magang diberi tugas untuk melakukan editing pada berita yang akan diterbitkan keesokan harinya.

Eneste (2012:8) mengemukakan pengertian menyunting adalah menyiapkan naskah siap cetak atau siap terbit dengan memperhatikan segi sistematika penyajian, isi, dan bahasa (menyangkut ejaan, diksi, dan struktur kalimat); mengedit. Kegiatan magang penyuntingan yang peserta magang lakukan adalah kegiatan editing naskah cetak sementara naskah berita. Berita adalah laporan terkini tentang fakta atau pendapat yang penting atau menarik bagi khalayak dan disebarluaskan melalui media massa (Yosef, 2009). Setiap hari peserta magang diberikan halaman-halaman koran Solopos untuk disunting. Halaman setiap koran berbeda-beda, misalnya halaman Sukoharjo, Wonogiri, Showbiz, Pagelaran, Boyolali, dan sebagainya. Setiap hari peserta magang diberikan halaman koran sebanyak 8-13 halaman koran yang berbeda-beda. 


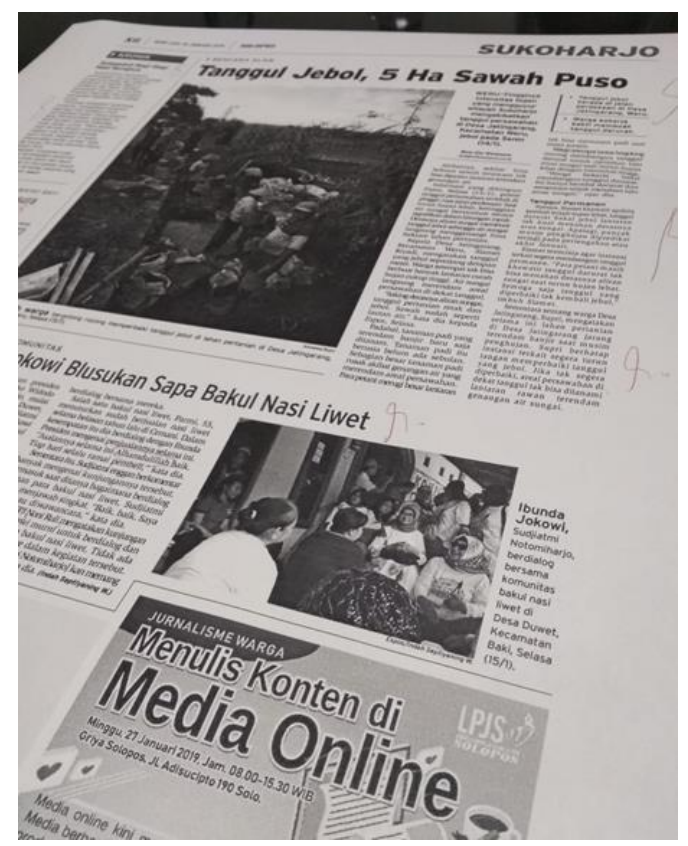

Gambar 1. Naskah yang disunting

Gambar di atas merupakan salah satu naskah yang telah disunting yang memiliki banyak tanda-tanda penyuntingan. Selama melakukan proses penyuntingan peserta magang menggunakan metode manual yaitu menandai kata atau ejaan yang kurang tepat. Kesalahan penulisan ditandai dengan spidol berwarna merah. Kesalahan dalam penulisan dilingkari dan di atas atau bawahnya diberikan pembetulannya. Jika teks berita sudah disunting, teks tersebut diberi tanda seperti di gambar. Peserta magang juga menggunakan pedoman berupa KBBI (aplikasi smartphone), buku Gaya Selingkung dari Solopos, dan PUEBI dalam proses penyuntingan. Setelah penyuntingan pada halaman tertentu telah selesai, penyunting mengembalikan halaman tersebut kepada penulis halaman tertentu tersebut. Setelah itu, penulis halaman tersebut akan menyunting kata atau ejaan yang salah melalui komputer.

\section{SIMPULAN}

Solopos merupakan salah satu lembaga yang dapat difungsikan sebagai laboratorium pendidikan bahasa Indonesia. Kegiatan magang penyuntingan dilakukan di Solopos. Solopos merupakan koran harian daerah Solo Raya. Oleh karena itu, Solopos menerbitkan koran setiap hari. Dengan begitu kegiatan penyuntingan pun dilakukan setiap hari. Hal ini menjadi tantangan bagi peserta magang untuk menyunting naskahnaskah berbeda setiap hari karena berita yang disajikan dalam koran setiap hari berbeda- 
beda. Selama melakukan proses penyuntingan peserta magang menggunakan metode manual yaitu menandai kata atau ejaan yang kurang tepat.

Kegiatan magang yang telah dilaksanakan dapat memberi berbagai pengalaman, bukan hanya dalam kegiatan penyuntigan, namun juga dalam keterampilan menjalin hubungan sosial dalam kehidupan dunia kerja. Dalam melakukan kegiatan penyuntingan, dua hal yang sangat diperlukan adalah ketelitian dan kepekaan terhadap kesalahan. Tidak lupa, juga perlu diimbangi dengan mengikuti perkembangan ilmu pengetahuan terbaru sehingga dapat memberikan data yang sahih dengan wawasan yang luas.

\section{DAFTAR PUSTAKA}

Dewan Pers. (2008). Peraturan Dewan Pers Nomor 6/Peraturan-DP/V/2008 tentang Kode Etik Jurnalistik. Jakarta: Dewan Pers Indonesia.

Eneste, P. (2012). Buku Pintar Penyuntingan Naskah. Jakarta: Gramedia Pustaka Utama. Pemerintah Indonesia. (2009). Peraturan Menteri Tenaga Kerja dan Transmigrasi No. Per.22/Men/IX/2009 tentang Penyelenggaraan Pemagangan di Dalam Negeri. Lembaran RI Tahun 2009 No. 22. Jakarta: Sekretariat Negara.

Primawan, Y. T. (2009). Mekanisme Kerja Reporter Kompas TV. Tugas Akhir Tidak Dipublikasi, Universitas Sebelas Maret, Surakarta.

Raharjo, Y. M., Suwandi, S., \& Saddhono, K. (2107). Kelayakan Buku Ajar Bahasa Indonesia Kelas VII Wahana Pengetahuan. BASASTRA, 5(2) 234-246.

Rhahmadani, S. A. \& Astuti, I. M. J. (2013). Proses Penyuntingan Kamus Pertanian Umum di Penerbit Penebar Swadaya. Jurnal Publipreneur, 1(2) 82-95.

Saddhono, K. (2012). Kajian Sosiolingustik Pemakaian Bahasa Mahasiswa Asing dalam Pembelajaran Bahasa Indonesia untuk Penutur Asing (BIPA) di Universitas Sebelas Maret. Kajian Linguistik dan Sastra, 24(2) 176-186.

Supriyana, A. (2018). Penyuntingan Aspek Kebahasaan dalam Naskah Berbahasa Indonesia. Arkhais, 9(2) 133-138.

Wikipedia. (2017). Solopos, diakses dari https://id.m.wikipedia.org/wiki/Solopos. Yosef, J. (2009). To Be Journalist. Yogyakarta: Graha Ilmu. 


\section{LAMPIRAN}

Berikut merupakan salah satu contoh kalimat yang memiliki kesalahan dan telah disunting. kalimat di bawah ini diambil dari harian Solopos berjudul "Tiket John Mayer Ludes, Netizen Menduga diborong Calo" pada tanggal 25 Januari 2019.

Yang pasti, di laman Bukalapak terdapat perinciran harga tiket konser John Mayer, mulai Rp1.440.000 hingga Rp4.960.000.

Kata yang dilingkari seharusnya ditulis perincian.

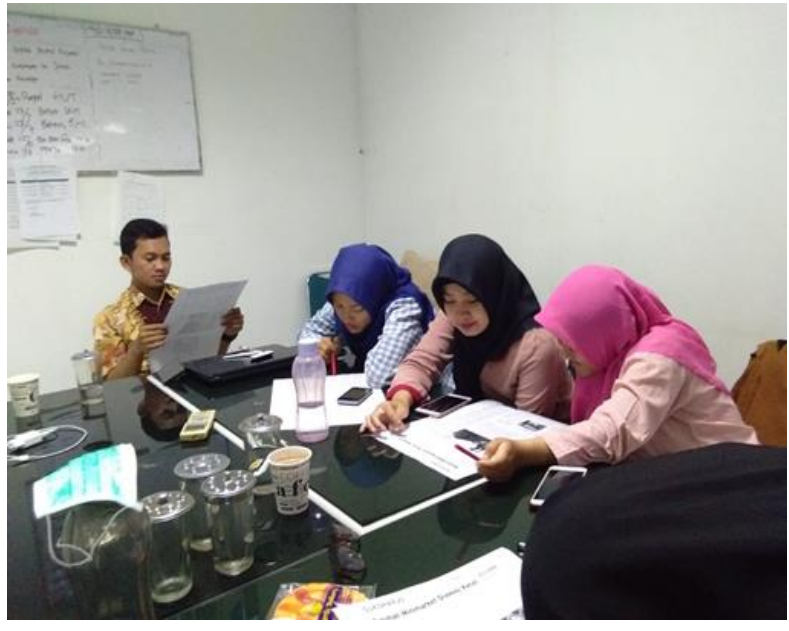

Gambar 2. Kegiatan menyunting naskah berita

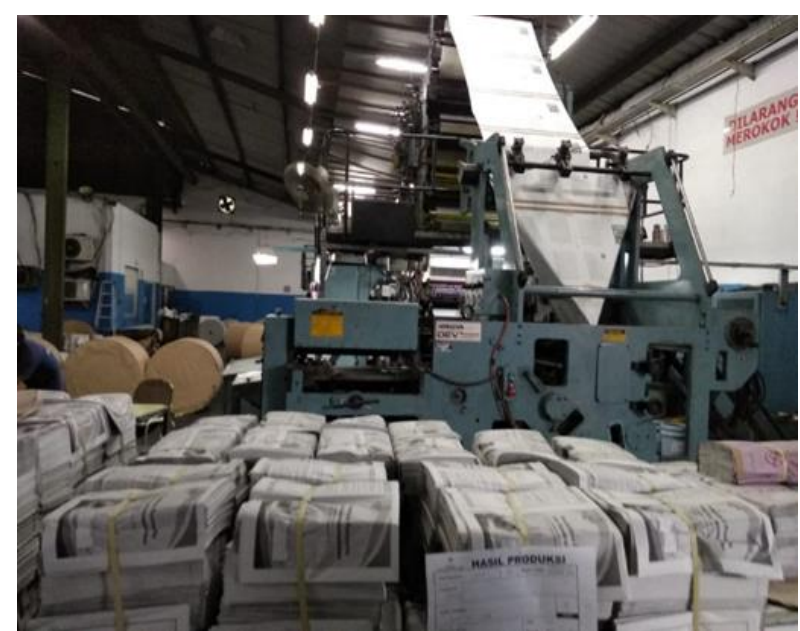

Gambar 3. Alat pencetak koran 